\title{
Cognitive Factors that Influence Principal Motivation in Mpumalanga Province
}

\author{
Steyn GM \\ Department of Educational Leadership and Management, College of Education, \\ University of South Africa, P.O. Box 392, Pretoria, 0003, South Africa \\ Email: steyngm1@unisa.ac.za
}

Mashaba SW

Doctorate student in Department of Educational Leadership and Management, College of Education University of South Africa, P.O. Box 392, Pretoria, 0003, South Africa

Doi:10.5901/mjss.2014.v5n16p381

\section{Abstract}

The need to conduct this study was necessitated by a lack of motivation among school principals in Mpumalanga province. This article reports on the findings from a formal study designed to develop a cognitive model to motivate principals in this province (Mashaba, 2012). The aim of this article was to identify cognitive factors that impact on the motivation levels of principals. A qualitative study, in particular a case study design, was selected while semi-structured interviews were employed as the primary data collection technique, corroborated and augmented by field notes and official documents. An interpretative approach was used to collect and analyse principals' experiences about factors they found motivating or de-motivating. The findings indicated that the motivation of school principals was influenced by their strategic focus, certain systemic factors in the school system and particular professional perceptions of their status as principal of a school. The study recommended that by consciously employing cognitive abilities the motivation of principals might be improved when they face problems and challenges in their leadership role.

Keywords: cognitive theories; motivation; school principals; leadership and management

\section{Introduction}

School principals play a key role in the provision of quality schooling. However, in doing so, they need to tackle numerous external, interpersonal and personal challenges in their profession (Khorshidi, Mirzamani \& Esfanhani, 2011:151; Mafora \& Schulze, 2012:227). One might assume that, in the face of constant transformation required by the new curriculum and governance, principals find themselves in difficult situations unable to cope with the demands of such developments (Botha, 2010:605; Moloi, 2004:2; Prew, 2007:447; Swanepoel, 2008:39). According to Bush, Joubert Kikkunde \& Van Rooyen (2009:6), this aggravates the situation and ultimately has a negative effect on school performance. They explain:

While poor learner achievement is often recognized, principals are prone to blame learners, their parents or lack of progress in their previous schools or grades, rather than accepting personal and collective responsibility for the poor learner outcomes.

Consequently, principals could feel demoralised, discouraged, de-motivated and dissatisfied to a point where some might even decide to quit the education system (Stemple, 2004:1).

One of the key challenges that has an impact on the optimal operation of schools worldwide, including South African schools, is the challenge associated with poor motivation among principals (Bush et al, 2009:6; Clarke, 2007:39; Tschannen-Moran \& Gareis, 2004:573). Motivation contributes considerably to the desires, drives, perceptions and the performance of school principals and forces them to respond by selecting a particular stimulus from various stimuli (Khorshidi et al, 2011:151). Expanding on this view, Bush et al (2009:6) declare that "most principals lack the capacity, or the motivation, to develop, sustain and monitor teaching and learning effectively". Similarly, Belle (2007:25) stresses that, although things such as training and physical resources are important for the realisation of the school's objectives, a school with state-of-the art facilities and resources might still fail to achieve its goals if the workforce is not properly motivated.

Since school principals are instrumental in providing quality leadership and management in their schools, their motivation to do so is pivotal (Mafora \& Schulze, 2012:227). Both international (McVay, 2007:5; Parker, 2007:9; Sodoma, 
2005:1; Stemple, 2004:1) and local (Clarke, 2007:257; Prinsloo, 2008:101) studies concur that poor motivation of principals is the main factor contributing to the poor achievement of school objectives. As Stemple (2004:1) observes, the complex tasks principals are expected to fulfil "... have caused them either to consider leaving the field entirely or to request classroom teaching assignments". Additionally, Tschannen-Moran and Gareis (2004:573) and Parker (2007:9) remark that good and motivated principals are the keystones of effective schools.

A number of studies were done on teacher motivation (Belle, 2007:158; Chindanya, 2002:123; Delahoo, 2011; Garudzo-Kusereka, 2003:165; George et al, 2008:144), but relatively few studies had been conducted in the field pertaining to the motivation of principals, especially in developing countries such as South Africa. The study by Khorshidi, Mirzamani and Esfanhani (2011) in Iran focused on factors that motivate principals, while the study by Schmittou (2011) demonstrated the relationship between personal motivation needs, workplace empowerment, and the attempted job stability of assistant principals in the school districts in southeast Michigan. The study by Mafora and Schulze (2012:238) on the job satisfaction of principals in the North-West province suggested that more research needs to be done on factors influencing their work situation as well as the self-efficacy beliefs of principals. Therefore, this study attempts to close such a gap while the knowledge gained could be used to improve the morale of principals in South African schools, especially in the Mpumalanga province. The research question that emerged in this study was: What cognitive factors influence the motivation of school principals in rural schools in Mpumalanga province?

In the context of the underperformance of schools in Mpumalanga province, there is the phenomenon of poor motivation among principals, which is characterised by tardiness, apathy, a low level of organisational commitment, complaints about the lack of resources, a lack of creativity in terms of confronting challenges, a lack of general interest in school activities and the display of unhelpful attitudes when assistance is needed by learners, educators and other stakeholders (Mpumalanga Annual Performance Plan, 2007:37; Bush et al, 2009:6; Nyathi, 2007:37). According to the Intermediate Phase Systemic Evaluation Report, Grade 6 (2005), 32.9\% of principals indicated that conditions in their schools were depressing and de-motivating. Therefore, it was unlikely that such discouraged, de-motivated and dissatisfied principals would be particularly effective and committed to their tasks over an extended period of time.

\section{Conceptual Framework}

For the purpose of this study motivation is defined as the complex set of forces, mechanisms or drives located internally or externally of the individual and which determine the intensity with which and direction the individual chooses to pursue or achieve set goals (Colquitt, Lepine \& Wesson, 2009:178; Delahoo, 2011:9; Khorshidi et al, 2011:151). However, understanding motivation and the factors that influence it, remains one of the most complex fields of education and psychology (Khorshidi et al, 2011:151).

Unlike the psychoanalytic approach, which views motivation as a product of unconscious impulses, and the behaviourist approach, which argues that motivation is shaped completely by environmental consequences (Pintrich \& Schunk, 2002:17), cognitive theorists contend that motivation is a function of cognitions, which include goals, needs, perceptions, beliefs, attitudes, expectations, values and other mental processes (Diefendorff \& Lord, 2003:371; Locke \& Latham, 2002:707; Pintrich \& Schunk, 2002:17). Individuals then evaluate, interpret, and make decisions regarding challenges posed by the environmental conditions, and these decisions, in turn, could result in increased interest, improved performance, and ultimately greater job motivation (Locke \& Latham, 2002:707; Shivers \& Blackwell, 2006:30)

The cognitive approaches chosen as a conceptual framework for the study include: McClelland's achievement motivation theory (McClelland, 1978), Locke's goal-setting theory (Locke, 1968) that specifies the processes and mechanisms that link goal-setting to a person's performance improvement; Vroom's expectancy theory (Vroom, 1964), which focuses on motivational explanations of performance; Adam's equity theory (Adam, 1963); Rotter's locus of control theory (1954 in Rotter 1990); and, Bandura's self-efficacy theory (Bandura, 1982), which states that self-efficacy beliefs affect people's cognitions, motivation and ultimately their behaviour.

According to McClelland's achievement motivation theory, the need for achievement refers to an "unconscious disposition to energise and drive, where individuals with high need for achievement for achievement are constantly competing with standards of excellence and success" (Locke \& Latham, 2002:705). Consistent with this view, Pintrich and Schunk (2002:194) substantiate that high achievers, unlike low achievers, are characterised by a strong wish "to accomplish something difficult, to master, to excel, to rival and surpass, to overcome obstacles and attain a high standard" in competitive situations.

Locke's goal setting theory emphasises the relationship between performance and goals (Locke \& Latham, 2002:706; Lunenburg, 2011:1). For goals to be successful, facilitating strategies such as feedback, clear goals, task complexity and support in the organisation are essentially linked to job performance (Delahoo, 2011:30; Locke \& Latham, 
2002:708). The motivation levels of individuals are influenced by moderators such as goal commitment and self-efficacy (Lunenburg, 2011:1).

In terms of the self-efficacy theory of Bandura, individuals' performance and motivation are determined by their perceptions or beliefs about their capabilities, competencies, abilities and skills to successfully perform a task (Bandura, 1982:122; Delahoo, 2011:2; Locke \& Latham 2006:265; Wood \& Olivier, 2004:289). Bandura's social cognitive model identifies three factors that influence a person's self-efficacy: behaviours, environment and personal/cognitive factors. People with high self-efficacy beliefs think that they are able to accomplish tasks and will therefore be motivated to act and achieve their goals.

According to Adam's equity theory, motivation is determined by an individual's views of fairness/unfairness in the awarding of rewards/punishment compared to what others have received (Colquitt et al, 2009:191; Delahoo, 2011:24; Kreitner \& Kinicki, 2001:223). A key aspect of the equity theory is, therefore, that individuals compare their inputs and rewards with those of other people.

Julian Rotter's theory postulates that motivation is determined by the "locus of control", which shows the extent to which individuals believe they can control certain internal or external events that affect them (Delahoo, 2011:54; Rotter, 1990:489; Shivers-Blackwell, 2006:31). This means that an individual with an internal locus of control thinks that he or she can affect events and their results, while a person with an external locus of control tends to blame outside forces for outcomes (Fournier \& Jeanrie, 1999:64).

Vroom's expectancy theory postulates that a person's motivation is the outcome of how much the person wants a reward (valence), the assessment that the effort will lead to the expected performance (expectancy) and the belief that the performance will produce a reward (instrumentality) (Kreitner \& Kinicki, 2001:230; Locke \& Latham, 2002:706). The theory suggests than people are motivated when there is a positive link between their efforts and performance; that favourable performance will lead to desirable rewards; that a reward will satisfy a certain need; and that this need is strong enough to make the effort worthwhile. This implies that people are motivated to act once they believe that their behaviours will lead to desired outcomes (Delahoo, 2011:24).

According to the cognitive theories outlined above, people are viewed as thinking beings that consciously use their thought processes to evaluate, interpret, understand and make future predictions regarding challenges and events experienced because of their environmental conditions. Subsequently, this can result in increased interest, greater effort, improved performance and greater job motivation (Locke \& Latham, 2002:707; Shivers \& Blackwell, 2006:30; Udechukwu, 2009:75). In addition, cognitive theorists believe that a greater level of job motivation can be achieved, if individuals set intrinsic goals, plan their course of action, put in sufficient effort and take full responsibility for the outcomes. In light of the above, principals who plan their work properly and take action to realise it, are more highly motivated than those who do not plan and do not take any action. Lastly, this approach was deemed to be the most relevant for this study because the contextual factors that de-motivated principals in the Mpumalanga province, especially in the Bohlabela district, were identified to be of a structural and systematic nature (Dlamini, 2004:62; Intermediate Phase Systemic Evaluation Report, Grade 6, 2005:64; Nyathi, 2007:37).

Since school principals have no direct input on the structure of the schooling system, it was felt that a cognitive approach to motivation was the most relevant when seeking to understand the challenges faced by principals in the Mpumalanga province.

\section{Research Design}

The aim of the study was to gain an in-depth understanding of the cognitive factors constituting the motivation levels of school principals. A qualitative research design, in particular a case study, was deemed most appropriate for the study, in a bounded system in the Bohlabela District (Cohen et al, 2007:155; Creswell, 2007:36). An interpretative approach was employed to gain first-hand information about the principals' subjective, although accurate, explanations of their managerial experiences regarding cognitive factors influencing their motivation (Nieuwenhuis, 2010:60). Data were collected through observation at schools, semi-structured interviews with participants, field notes, and official school and departmental documents.

Purposive sampling was used to select participants and the data reached saturation level after fifteen participants in the Bohlabela district, in Mpumalanga province, had been interviewed (Creswell, 2007:160). The profiles of the principals, seven males and nine females, were drawn from nine primary schools and six secondary schools across the district These schools were all identified as rural schools and had been officially declared to be "no fee schools" (Mpumalanga, No Fee Schools, 2010) and were benefiting from the school feeding programme. They are also relatively well resourced. This fact minimised the tendency of participants to complain about the insufficiency of resources when 
accounting for their performance. The profiles of the participating schools are depicted in the table 1.

Table 1: Profiles Of Participating Schools

\begin{tabular}{|c|c|c|c|c|c|c|c|c|c|c|c|c|c|}
\hline \multirow[b]{2}{*}{ 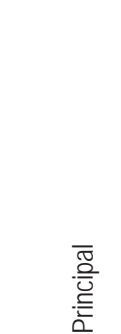 } & \multirow[b]{2}{*}{$\begin{array}{l}\overline{0} \\
\text { 음 } \\
\text { w }\end{array}$} & \multirow[b]{2}{*}{ 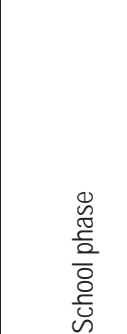 } & \multirow[b]{2}{*}{ 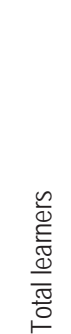 } & \multirow[b]{2}{*}{ 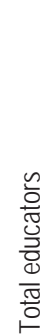 } & \multirow[b]{2}{*}{ 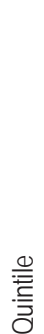 } & \multirow[b]{2}{*}{ 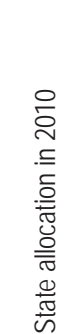 } & \multirow[b]{2}{*}{ 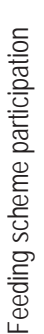 } & \multicolumn{6}{|c|}{ Basic facilities available } \\
\hline & & & & & & & & 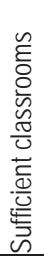 & 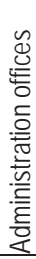 & 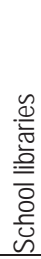 & 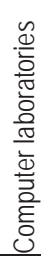 & 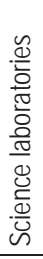 & 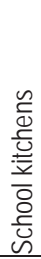 \\
\hline Principal A & School A & Secondary & 868 & 32 & 2 & R 784 & $\checkmark$ & $\mathrm{x}$ & $\checkmark$ & $x$ & $\mathrm{x}$ & $x$ & $x$ \\
\hline Principal B & School B & Primary & 1199 & 35 & 2 & R 784 & $\checkmark$ & $x$ & $\checkmark$ & $x$ & $x$ & $x$ & $\checkmark$ \\
\hline Principal C & School C & Primary & 916 & 27 & 1 & R 855 & $\checkmark$ & $\checkmark$ & $\checkmark$ & $\mathrm{x}$ & $\mathrm{x}$ & $\mathrm{x}$ & $\checkmark$ \\
\hline Principal D & School D & Primary & 985 & 29 & 1 & R 855 & $\checkmark$ & $\checkmark$ & $x$ & $\checkmark$ & $x$ & $x$ & $x$ \\
\hline Principal E & School E & Secondary & 1123 & 42 & 1 & R 855 & $\checkmark$ & $\checkmark$ & $\checkmark$ & $\checkmark$ & $\checkmark$ & $\checkmark$ & $x$ \\
\hline Principal F & School F & Secondary & 515 & 19 & 2 & R 784 & $\checkmark$ & $\checkmark$ & $\checkmark$ & $\checkmark$ & $x$ & $\checkmark$ & $\checkmark$ \\
\hline Principal G & School G & Secondary & 646 & 23 & 2 & R 784 & $\checkmark$ & $\checkmark$ & $\checkmark$ & $x$ & $x$ & $x$ & $X$ \\
\hline Principal H & School H & Primary & 409 & 12 & 1 & R 855 & $\checkmark$ & $\checkmark$ & $\checkmark$ & $\checkmark$ & $\checkmark$ & $x$ & $\checkmark$ \\
\hline Principal I & School I & Primary & 347 & 10 & 2 & R 784 & $\checkmark$ & $\checkmark$ & $\checkmark$ & $x$ & $x$ & $x$ & $X$ \\
\hline Principal J & School J & Primary & 358 & 11 & 2 & R 784 & $\checkmark$ & $\checkmark$ & $\checkmark$ & $x$ & $x$ & $x$ & $\checkmark$ \\
\hline Principal K & School K & Secondary & 1440 & 54 & 1 & R 855 & $\checkmark$ & $\checkmark$ & $x$ & $x$ & $\checkmark$ & $x$ & $\checkmark$ \\
\hline Principal L & School L & Primary & 963 & 28 & 2 & R 784 & $\checkmark$ & $\checkmark$ & $\checkmark$ & $\checkmark$ & $\checkmark$ & $x$ & $\checkmark$ \\
\hline Principal M & School M & Primary & 522 & 16 & 1 & R 855 & $\checkmark$ & $\checkmark$ & $x$ & $x$ & $x$ & $x$ & $x$ \\
\hline Principal N & School N & Primary & 187 & 6 & 2 & R 784 & $\checkmark$ & $x$ & $x$ & $x$ & $x$ & $x$ & $\checkmark$ \\
\hline Principal O & School O & Secondary & 627 & 24 & 1 & R 855 & $\checkmark$ & $\checkmark$ & $\checkmark$ & $\checkmark$ & $\checkmark$ & $\checkmark$ & $x$ \\
\hline
\end{tabular}

In the analysis of the data, all the interview transcriptions were thoroughly read, segmented and inductively coded into themes, categories and sub-categories (Johnson \& Christensen, 2011:520). To ensure that the research findings could be trusted, reliable, replicable and valid, the following strategies were used: multi-method techniques were applied and a tape-recorder was used to record verbatim accounts of all the interviews, which were subsequently transcribed (Cohen et al, 2007:176). The transcriptions of the interviews were given to principals in order for them to verify the authenticity thereof and, thus, ensure the correctness of the data.

Ethical measures included the following: permission was obtained from the Department of Education in Mpumalanga to conduct the research; participants were informed about the proposed study and their informed consent were obtained; and participants' identity, confidentiality and anonymity were honoured (McMillan \& Schumacher, 2010:119).

The study employed Lincoln and Guba's (1985) four criteria of trustworthiness, namely credibility, dependability, confirmability and transferability (Polit \& Beck, 2008:539). To confirm credibility, all interviews were recorded, transcribed and analysed, which included prolonged engagement in schools as well as member-checking to ensure the accuracy of data. By means of a dense description of the research design, dependability was ensured. Bracketing was used to guard against bias and subjectivity and confirmability was ensured through the use of triangulation in the study (Wall et al, 2004:21). Finally, sufficient and appropriate descriptive information was used and presented in this study to ensure transferability.

\section{Research Findings}

Four main themes emerged from the data: a strategic focus; systemic factors impacting on motivation; quality of the support; and the principals' professional perceptions. In the following sections these categories and subcategories are briefly outlined. 
Table 1: Categories And Sub-Categories

\begin{tabular}{|c|l|}
\hline Category 1 & 1. A strategic focus \\
Sub-category 1 & a. The school vision \\
Sub-category 2 & b. Facilitating strategies \\
Sub-category 3 & c. Passion for learner success \\
\hline Category 2 & 2. Systemic factors impacting on motivation \\
Sub-category 1 & a. Quality of the teaching and learning processes \\
Sub-category 2 & b. Quality of the support \\
\hline Category 3 & 3. The principals' professional perceptions \\
Sub-category 1 & a. Need for appreciation \\
Sub-category 2 & b. Self-efficacy belief \\
Sub-category 3 & c. C. Locus of control \\
\hline
\end{tabular}

\subsection{A strategic focus}

The findings reveal that the ability of principals to perform specific activities (facilitating strategies) linked to predetermined goals (the school vision) and a passion for learner success had significant intrinsic value and enhanced their motivation. These findings are discussed in the following sub-sections.

\subsubsection{The School Vision}

A school vision, stipulating specific goals, was found to be a significant determinant of motivated behaviour among principals. Participants agreed that they wanted their learners to succeed in life as, expressed by Principal B, who said: "We want to see many doctors from the school here and many engineers from the school here." However, a lack of commitment and illiteracy among learners were identified as a major challenge by all the participants. They indicated that this also affected their motivation levels.

The research findings confirmed Locke's goal setting theory that specific and difficult goals have a strong motivational effect that guide people's actions. A subsequent study of Locke and Latham (2002:707) also found that these goals, if accepted, can lead to better performance. Similarly, other studies conclude that principals, who establish a clear school vision and pursue it actively and persistently, are able to make a positive impact on school performance. It is equally crucial to explore the facilitating strategies that are critical when leaders are striving to attain organisational goals (Athanasoula-Reppa \& Lazarido, 2008:65; Diefendorff \& Lord, 2003:369; Khuzwayo, 2008:96).

\subsubsection{Facilitating Strategies}

The data revealed that the ability of principals to develop and implement performance strategies to attain a school vision had a significant effect on their morale. It was noteworthy that participants developed performance strategies that were simple, specific and concrete. The facilitating strategies included the development and implementation of strategic, operational and instructional plans to attain school goals. In this regard, Principal A, stated that, "... unlike [in] previous years, we adopted progressive programmes that will assist in improving our Grade 12 results. This motivates us a lot".

Some schools have also developed systems to track the performance of their learners. According to the participants, the development of the performance strategies had a strong motivational impact on them. Principal $O$ remarked that "better performance of my learners at secondary school makes me proud". A passion for learner success generated a deeper sense of focus, enthusiasm and commitment among school principals. Principals were particularly concerned about the poor reading and writing skills of learners and they had developed collective strategies together with teachers to assist these learners.

These findings confirmed Locke's goal-setting theory, which states that, for the goal to have a significant motivational effect, facilitation strategies need to be developed and implemented. Expanding on this theory, Diefendorff and Lord (2003:381), Lunenburg (2011:1) and Garber (2006:2) found that principals with the necessary facilitation strategies to improve school performance built teamwork and expertise and dealt effectively with a rapidly changing school environment. The findings are also in line with Vroom's expectancy theory that suggests that principals could be motivated when there is a positive link between their efforts and performance (Kreitner \& Kinicki, 2001:230). 


\subsubsection{A Passion for Learners}

The participants agreed that their learners deserved a brighter future. It was also found that some principals had gone beyond the call of duty when it came to assisting needy learners, particularly in terms of assisting them to pass Grade 12 with excellent results. Although the reasons for their passions differed, the need for learner achievement and fulfilment were the main driving force behind the efforts of participants. The principal of School $\mathrm{C}$ noted:

As a teacher, I have passion for teaching and also that, I too, have been a learner and somebody did something good to me and I am here today, for I feel obliged to have this dream so that at the end; these learners should be saying: "Yes, they did something to us".

The findings confirm McClelland's achievement motivation theory that an individual's passion and desire for success were the primary determinants of human motivation in the workplace (Pintrich \& Schunk, 2002:194). McClelland's achievement motivation theory further postulates that high-achievers have a strong passion for finding solutions to problems, mastering complex tasks, setting realistic goals and obtaining feedback on the level of their success. These findings are also supported by Rotter's locus of control theory that suggests than a person is motivated when there is a positive link between his or her efforts, that satisfactory performance will lead to appropriate rewards, and that a reward will satisfy a particular need which is strong enough to make the effort worthwhile.

Another group of factors that affected the motivational levels of principals pertain to systemic factors in the school system.

\subsection{Systemic Factors Impacting on Motivation}

Within this category the following subcategories emerged: quality of the teaching and learning processes, the quality of support from the Department of Education and the quality of support from the various stakeholders.

\subsubsection{Quality of the Teaching and Learning Processes}

The quality of teaching and learning processes were found to be a critical motivational factor for principals. Principals indicated that their motivation levels became very low when learners were not committed and did not take responsibility for their studies. They expressed their dissatisfaction about their learners' commitment to learning as well as learners' inability to read and write. Principal K raised her concern by indicating that "we have learners, even in Grades 11 and 10 ... who are unable to read, they cannot write, not English as additional language... even Xitsonga as a home language". Such experiences discourage them from executing their day-to-day managerial tasks.

The contrary, however, also became evident; principals felt satisfied when their learners showed an interest in their own learning. In this regard, the principals of School $\mathrm{L}$ and School $\mathrm{F}$ remarked that good performance by learners was experienced as "very encouraging" and "positive". Concerning the contributory factors to the poor performance of learners, the principal of School D attributed these to the fact that "most of the children were not living with their parents. Their parents are working far".

The study also revealed that the commitment of teachers had a significant effect on the morale of principals. Participants were motivated when educators performed well and became de-motivated when educators performed below expectations. The principal of School O remarked that "... the level of commitment ... is satisfactory ... All teachers are in their classes". In contrast, principals were unhappy with teachers who were uncommitted, who dragged their feet when going to class and who failed to discipline their learners. A similar concern was raised by Principal O, who indicated that she constantly had to remind teachers to do their work and tell them to: "Go to your class; go to your class!"

The responses also showed that the commitment of the school management teams (SMTs), especially with regard to the monitoring of teaching and learning processes, had a significant impact on the morale of principals. The willingness and commitment of the SMT to confront challenges relating to the teaching and learning processes were highly appreciated and had a direct impact on the morale of principals. Through team work, some principals were able to meet regularly to plan and assess their school performance. Such team work enabled schools to monitor processes and also to determine if teachers and learners were doing their work.

Principals cited several strategies for mitigating and enhancing learner performance (poor reading, writing and counting). The availability of these strategies at schools to counteract poor learner performance had a significant impact on the morale of principals. Participants alluded to introducing initiatives such as extra classes, afternoon lessons, and lessons over weekends and school holidays. On this score, the principal of School J explained: "We are doing everything in our power to let them study, to let them come during week-ends and even during school holidays." The principal of 
School $\mathrm{N}$ indicated that these initiatives "really" led to the improvement of learner performance. Principals agreed that such successful initiatives were highly motivational.

Enhancing learner commitment alone was insufficient to have a meaningful motivational impact on principals. Principals concurred that the performance of their staff had a direct impact on their motivation levels. The findings show that the availability of strategies to increase educators' commitment to the teaching processes significantly influenced the level of enthusiasm of principals. Positive strategies such as teacher professional development, workshops and extra lessons had a high motivational value. The teachers in schools were encouraged to attend training sessions and cluster meetings to develop professionally and thereby enhance their teaching performance.

Similarly, the interviews revealed that the availability of strategies to address poor parental support also enhanced a sense of enthusiasm and commitment in principals. There was consensus among the participants that the strategy of regular meetings with parents was highly successful. Participants like Principal K had organised "a block meeting and book viewing ... where we display the work of learners" to parents. Based on principals' views, it was clear that parents benefited a great deal from such interventions in schools and this, in turn, influenced the enthusiasm of principals.

The exposition above supports Locke's goal setting theory (1968), which states that there is a linear and positive goal-performance relationship between goal acceptance and commitment to school performance. Subsequent studies by Locke and Latham (2002:708) found that people who know how they are doing are able to adjust the level or direction of their effort or adjust their performance strategies. Similarly Bush et al (2009:6) maintain that principals have a great responsibility to ensure educator commitment by means of developmental programmes. On this score, The Mpumalanga Annual Performance Plan (2005) recommends that principals should continue to work cooperatively with the school management team because, together, they are responsible for "assuring the quality of teaching and learning in schools". The findings are also supported by McClelland's achievement theory that shows the need of principals for achievement and success and Vroom's expectancy theory that indicates how much effort principals will put in to be rewarded by learner success. The findings are also confirmed by Belle (2007:122) and Mthombeni (2004:84), who assert that the academic performance of learners has a significant impact on the morale of principals, while Fisher (2009:39) and Georgiou (2007:59) maintain that principals must intentionally create a suitable climate so that parents would feel welcome and appreciated.

\subsubsection{Quality of the Support}

Considering the physical resources of the schools in the study, the findings showed that participants were generally dissatisfied with the quality of support they received from the Department of Education. However, the state of the curriculum delivery in schools contributed significantly to principals' lack of motivation, while ongoing, "never-ending", curriculum reviews frustrated them. The principal of School $\mathrm{H}$ explained:

It [the curriculum] is changing nearly every day. When one tries to grasp, the curriculum changes to another ... this de-motivates us ... We try to acquaint ourselves with the curriculum, but it is difficult.

In addition to continuous changes to the curriculum, participants were also concerned about the quality of support received from the curriculum implementers. According to them, these curriculum implementers took a long time before visiting their schools and often arrived at the wrong time. Moreover, the arrangement of having cluster committees to provide suitable guidelines as well as feedback on the implementation of the curriculum was criticised. Principal E, therefore, noted that cluster committees operated haphazardly and did not have a proper plan to guide their teaching in classrooms.

These findings confirm Locke's goal setting theory about the effect of feedback after completion of a task, particularly in terms of whether the set goals have been attained or not. Subsequent studies conducted by Maxwell (2006:46), Mills (2005:14) and Moloi (2004:2) highlighted the fact that external factors, like the on-going curriculum changes, do affect school performance and, as such, the motivation levels of principals.

Principals' motivation was negatively affected when financial resources, particularly funds allocated from the department, were inadequate to meet their school's needs. On this score, the principal of School K insisted, "The money is not sufficient ... This de-motivates us a lot." Similar sentiments were shared by other principals, as some of them mentioned that their learners were not paying school fees and that they found it difficult to maintain the school owing to limited financial resources. The opposite, however, also became evident; principals' motivation increased considerably when funds were sufficient to address their schools' financial needs. In this regard, the principal of School L remarked: "I have a functional SGB... We budget, we prioritise what we are going to do for the year, and we try by all means to stick on what we have planned."

In addition, some participants complained about the quintile ranking of their schools. This ranking affected their 
annual allocation from the Department of Education. The main concern of a few principals was that their schools were in a higher or in the wrong quintile; mostly 2 or 3 , which was regarded as unfair because it differed from neighbouring schools, which shared similar geographic settings and poverty levels. Moreover, participants complained that the Department of Education was unfair with regard to the allocation of physical resources; needy schools were not provided with sufficient physical resources, while such resources were given to less needy schools. Although the schools in the study were relatively better resourced than many of the other rural schools in the district, all of them complained about the shortage of physical facilities at their schools, particularly administration offices, classrooms and specialised classrooms like libraries, school halls and laboratories. In this regard, the principal of School O complained that "there are other factors that ... are disturbing in the school like [the lack of] enough water, enough toilets, especially girls' toilets". Moreover, participants believed that the Department of Education was unreliable and did not keep its promise to provide sufficient physical facilities. The principal of School E complained that "it is the fourth year waiting the three classes the department promised us for senior phase learners. It is really discouraging".

These findings confirm Adam's inequity theory that principals perceive unfairness when they felt that the ratio of the provision of physical facilities is far less than their inputs (loyalty, diligence) compared to other schools. Chindanya (2002:52) states that such perceptions of unfairness will always affect the motivation of principals. In this regard Moloi (2007:470) adds that, unsurprisingly, the "wretched physical conditions" at many schools affect principals negatively.

Another concern that principals raised was the shortage of personnel at schools, particularly teachers and administrative staff, and how this had a significant de-motivational effect on their morale. According to the participants, the Department of Education was unwilling to advertise posts. The principal of School F remarked that "this is third year our administrative clerk post hasn't been advertised". Participants also complained about their learner-teacher ratios, and a shortage of mathematics and science educators. Such challenges prevented the attainment of school goals and, subsequently, their motivation levels.

Again, these findings support Adam's inequity theory that principals perceived unfairness when they felt that the provision of personnel differs from their post establishment compared to other schools. Similar studies conducted by Davidson (2007:159) and Ediger (2009:574) contend that correct staffing is critical for the smooth running of schools.

The quality of support principals receive from parents also plays an important role in terms of principal's motivation. Seven of the fifteen participants felt unsupported by the parents, especially in areas such as attending parental meetings, assisting children with their school work and also financial contributions to school activities. The principal of School N remarked that "parents don't cooperate". Principals attributed this lack of parental support to illiteracy among and the laziness of some parents. "Parents in our community are so illiterate or are too lazy to be able to assist their learners with school work," according to Principal C. The opposite, however, also became evident; some participants felt satisfied with the role played by parents at their schools. According to them, parents attended meetings, volunteered for school projects, ensured that learners attend classes regularly and assisted with the maintenance of school discipline. The principal of School G, specifically, expressed his appreciation as follows:

When we call them [parents] to school and discuss the problems of learners; they are always prepared to come. They support us, though most of them are illiterate. But they are interested in the education of their children.

The data revealed that principals' morale increased considerably when their school governing bodies (SGBS) provided them with the necessary support. The principal of School N expressed the view that her SGB went as far as "even the fixing of doors". Participants agreed that their SGBs contributed a great deal by maximising discipline and order at their schools.

Responses from principals showed that their motivation levels dropped when unions disrupted schools, while their motivation levels increased when they perceived the role played by unions as constructive. In this regard, the principal of School J complained about numerous strikes which disturbed the normal running of schools and "de-motivated" him: "When you are in a strike, you end up not achieving some of the things, especially the objectives you have set for yourself before."

The above exposition confirms Vroom's expectancy theory (1964), which maintains that organisational support that is, teachers, parents, SGB and union support - could facilitate and strengthen the effort-performance relationship of principals, which was not always the case at some of the participants' schools. These findings are also in congruent with the views of Georgiou (2007:60) and Mbatsana, (2006:79), who assert that a lack of parental support reduces the enthusiasm of educators in the school. With regard to unions, Painter (2000:3) and Toffelson (2000:65) substantiate the view that organisational support in the form of labour unions is needed to strengthen people's reasonable anticipation that their effort will lead to the desired outcomes. 


\subsection{Principals' professional perceptions}

The data suggested that the principals' professional perceptions, particularly the need for appreciation, a self-efficacy belief and a locus of control, are important determinants of motivation in principals.

\subsubsection{Need for Appreciation}

The responses from the interviews, as corroborated by the data from the observational field notes, revealed that the morale of principals improved when they were appreciated and acknowledged for work well done. Participants expressed their satisfaction for being awarded trophies, certificates and prize monies from the Department of Education, their colleagues, parents, or community members. In schools such trophies and certificates were clearly displayed in the principals' office and staff rooms as a sign of appreciation and acknowledgement. On this score, the principal of School $\mathrm{H}$ explained how much her beautification of the school grounds was appreciated, and that she felt "very honoured and great". Furthermore, the recognition and appreciation from both the parents and community members were valued by principals. However, the findings also confirmed that principals' morale deteriorated when they felt unappreciated and unacknowledged for their work.

These findings confirmed Vroom's expectancy theory (1954)., according to which a person's motivation is the outcome of how much the person wants a particular reward, the assessment that the effort will lead to the expected performance and the belief that the performance will produce a reward. The subsequent research (Garudzo-Kusereka, 2003:26; Udechukwu, 2009:75) has shown that self-esteem needs are partly met by recognition, acknowledgement and appreciation of the work and contributions of principals, either in the form of praise, medals or promotions. The need for acknowledgement of performance implies that such a need may be based on principals' self-efficacy beliefs.

\subsubsection{Self-efficacy beliefs}

The responses revealed that principals' self-efficacy beliefs had a significant effect on their motivation. In other words, principals who believed in their abilities and skills were highly motivated. In this regard, the principal of School G pointed out: "I do believe in myself. I always try to manage the school professionally ... I don't stop from learning. All these motivate me." A similar sentiment was shared by Principal $\mathrm{K}$, who felt that her school performance was a product of her effort, diligence and hard work, not merely a matter of luck.

The findings also showed that principals who believed in their abilities tended to engage in activities that enhanced their motivation. A number felt equipped to accept and address their challenges. These findings supported Bandura's self-efficacy theory, that is, that the highly self-efficacious principals are found to be persistent, steadfast, more flexible and are more willing to adopt new strategies in pursuit of their goals. The subsequent studies of Awang-Hashim, O'Neil and Hocevar (2002:344) and Woods and Olivier (2004:292) concur that highly self-efficacious principals believe in their own abilities and skills, rather than believing in external forces such as luck and chance, as also shown in this study. In addition to the self-efficacy belief, the locus of control is another factor that may impact the motivation of principals.

\subsubsection{Locus of control}

From the data it was clear that the locus of control has a significant effect on the morale of principals. Although some principals were willing and prepared to face their challenges, a number of participants complained and blamed their problems on various external factors instead of taking personal responsibility. For example, Principal $\mathrm{N}$ complained about the poor cooperation of parents, Principal M about the commitment of teachers and Principal $E$ about the support from the Department of Education.

The findings support Rotter's locus of control theory, which states that individuals who take personal responsibility for the outcome of their efforts are more motivated than those attributing the outcome to environmental factors only. Subsequent studies also found that internally oriented principals exhibit greater confidence, are more capable of handling stressful situations, pursue riskier and more innovative strategies, and deliver a better performance than do externallyoriented principals (Shivers-Blackwell, 2006:32; Chen \& Silverthorne, 2008:573; Graffeo \& Silvestri, 2006:593).

\section{Conclusion}

This study uncovered cognitive factors that influenced the motivation of principals in the Mpumalanga province. The 
ability of principals to take responsibility for the attainment of their school's goals including the established school visions, facilitating strategies and their passion for learner success had an intrinsic motivational effect on principals. Likewise, the tendency of principals to rely on appreciation, and acknowledgement from others had an impact on their intrinsic motivational level. This implies that the ability of principals to consciously apply their cognitive abilities and to confront the challenges imposed by the extrinsic environment enhanced their motivation. This means that if principals were able to take personal responsibility for their behaviour when facing negative situations, it could have a significant motivational effect; particularly as it relates to increased effort and improved performance.

However, where principals blamed extrinsic factors for their performance and the poor performance of others, it had a significant de-motivating effect on principals and their performance. Extrinsic factors included the lack of appropriate information on curriculum issues, allocation of state finances, provision of physical facilities and staff and the management of stakeholders. Therefore, when dealing with challenges imposed by extrinsic factors, principals could be in a position to consciously use of their cognitive abilities in pursuing their school goals; rather than depending on uncontrollable extrinsic forces. As such principals could be in a position to take full responsibility for the outcomes of their efforts and performance which would ultimately influence their motivation levels. I agree with Bandura (2000:120) that "when faced with obstacles, setbacks, and failures, those who doubt their capabilities slacken their efforts, give up, or settle for mediocre solutions. Those who have a strong belief in the capabilities redouble their effort to master the challenge".

\section{References}

Adams, J.S. (1963). Toward an understanding of inequity. Journal of Abnormal and Social Psychology, 67, 422-436.

Alieg-Mielcarek, J.M. (2003). A model of school success: instructional leadership; academic press, and student achievement. Doctoral dissertation. Ohio: The Ohio State University.

Athanasoula-Reppa, A. \& Lazaridou, A. (2008). Requirements, roles, and challenges of the principalship in Greece and Cyprus. Newly appointed principals' views. European Education Fall, 40(3):65-88.

Awang-hashim, R., O'Neil JR, H.F. \& Hocevar, D. (2002). Ethnicity, effort, self-efficacy, worry and statistics achievement in Malaysia: a construct validation of the state-trait motivation model. Educational Assessment, 8(4), 341-364.

Bandura, A. (1982). Self-efficacy mechanism in human agency. American Psychologist. 37(2), 122-147.

Bandura, A. (2000). Cultivate self-efficacy for personal and organizational effectiveness. In E.A. Locke (Ed.). The Blackwell handbook of principles of organizational behaviour (pp. 120-136). Oxford, Malden, MA.

Belle, L.J. (2007). The role of secondary school principals in motivating teachers on the Flacq District of Mauritius. Master's dissertation. Pretoria: University of South Africa.

Bush, T.; Joubert, T.; Kiggundu, E. \& Van Rooyen, J. (2010). Managing teaching and learning in South African Schools. International Journal of Educational Development, 30, 162-168.

Chindanya, A. (2002). Motivating professional staff as a managerial task at a higher education institution. Master's dissertation. Pretoria. University of South Africa.

Clarke, A. (2007). The handbook of school management. Cape Town: Kate McCallum.

Cohen, L.; Marion, L. \& Morrison, K. (2007). Research methods in education. (6th ed). London: Routledge.

Colquitt, A.; Lepine, J.A. \& Wesson, M.J. (2009). Organizational behaviour: Improving performance and commitment in the workplace. New York, NY: The McGraw-Hill.

Creswell, J.W. (2007). Research design: qualitative, quantitative and mixed methods approaches. (3rd ed.). London: Sage.

Davis, J. \& Wilson, S.M. (2000). Principals' efforts to empower teachers: effect on teacher motivation and job satisfaction and stress. The International Journal of Educational Management, 73(6), 349-353.

Delahoo, G. (2011). The motivation and job satisfaction of secondary school teachers in KwaZulu-Natal: an education management perspective. Doctor of Education thesis. Pretoria: University of South Africa.

Diefendorff, J.M. \& Lord, R.G. (2003). The volitional and strategic effects of planning on task performance and goal commitment. Human Performance, 16(4), 365-387.

Fisher, Y. (2009). Defining parental involvement: the Israeli case. US-China Education Review, 6(11), 33-45.

Fournier, G. \& Jeanrie, C. 1999. Locus of control. Journal of Career Assessment, January 7(1), 63-89. [Online] Available: http://psychcentral.com/encyclopedia/2009/locus-of-control/ (March 20, 2013).

Garber, N. (2006). Strategic planning model and terminology. London: Nathan Garber.

Garudzo-Kusereka, L. (2003). Factors influencing the motivation of Zimbabwean secondary school teachers: an education management perspective. Master's dissertation. Pretoria: University of South Africa.

Graffeo, L.C. \& Silvestri, L. (2006). Relationship between locus of control and health-related variables. Education, 126 (3), $593-596$.

Intermediate Systemic Evaluation Provincial Report, Grade 6. (2005). Mpumalanga Department of Education. Nelspruit: Government Printers.

Johnson, B. \& Christensen, L. (2011). Educational research: quantitative, qualitative, and mixed approaches. (4th ed.). Thousand Oaks, California: Sage. 
Khorshidi, A. Mirzamani, S.M. \& Esfanhani, H.D. (2011). Effective factors in enhancing school managers' job motivation. Iran Journal of Psychiatry 6, 51-157.

Khuzwayo, M.N. (2008). The assessment of instructional leadership in schools: implications for whole school evaluation. Master's dissertation. Johannesburg: University of Johannesburg.

Kreitner, B. \& Kinicki, A. (2001). Organisational behaviour. 4th edition. New York: Irwin McGraw-Hill.

Latham, G.P. \& Pinder, C.C. (2005). Work motivation theory and research at the dawn of the twenty-first century. Annual Reviews of Psychology, 56, 485-516.

Lincoln, Y.S. \& Guba, E.G. (1985). Naturalistic inquiry. London: Sage.

Livesey, C. 2006. Sociological research methods. [Online] Available: http://www.sociology.org.uk/revgrm5.pdf (August 22, 2010).

Locke, E.A. \& Latham, G.P. (2002). Building a practically useful theory of goal setting and task motivation. American Psychologist 57 (9):705-717.

Locke, E.A. (1968). Toward a theory of task motivation and incentives. Organizational Behavior and Performance 3:157-189. [Online] Available: http://coachsci.sdsu.edu/csa/vol22/locke1.htm (March 19, 2013].

Locke, E.A. \& Latham, G.P. (2006). New direction in goal setting theory. Association for Psychological Science, 15(5), 265-268.

Lunenburg, F.C. (2011). Goal-Setting Theory of Motivation. International Journal of Management, Business and Administration, 15(1), 16.

Mabuza, D.D. 13 October (2011). Address by Hon. Premier DD Mabuza at the meeting with school principals. Nelspruit: Premier's office.

Mafora, T.P. \& Schulze, S. (2012). The job satisfaction of principals of previously disadvantaged schools: new light on an old issue. South African Journal of Education, 3, 227-239.

Maree, K. (Ed.) (2010). First steps in research. Pretoria: Van Schaik.

Masango, S. 2007. Remarks by the MEC for Education, Mr Siphosezwe Masango on the occasion of the meeting with RCLs in the Bushbuckridge region. Nelspruit: Mpumalanga Department of Education.

Mashaba, S.W. (2012) Developing a Cognitive Model to Motivate School Principals in the Mpumalanga Province. Doctoral thesis: University of South Africa, Pretoria.

Maxwell, J.C. (2006). The difference maker. Making your attitude your greatest asset. Nashville: Thomas Nelson.

Mbatsana, P.N. (2006). The financial accountability of school governing bodies. Master's dissertation. Pretoria: University of Pretoria.

McClelland, David C. (1978). Managing motivation to expand human freedom. American Psychologist, 33(3), 201-210.

McMillan, J.H. \& Schumacher, S. (2010). Research in education: evidence- based inquiry. Boston: Pearson.

Mestry, R. (2006). The functions of school governing bodies in managing school finances. South African Journal of Education, 26 (1), 27-38.

Mhaule, R.M. 24 May (2011). Budget and policy speech for 2011-12 financial year to be tabled by the MEC for Education, Mrs Regina Mhaule on 24 May 2011 at the provincial legislature. Nelspruit: Mpumalanga Department of Education.

Mills, Q.M. (2005). How to lead, how to live. The Importance of Leadership. [Online] Available: http://www.mindedpress .com?PDFs?htlhtl.pdf_March 8, 2010].

Motshekga, A. 05 September 2011. Address at the 16th SAOU school principal symposium by Mrs Angie Motshekga, Minister of Basic Education. Port Elizabeth: Department of Education.

Mpumalanga'S No Fee Schools. Mpumalanga Department of Education. (2010). Nelspruit: Government Printers.

Nieuwenhuis, J. (2010). Introducing qualitative research. In K. Maree (Ed.). First steps in research (pp. 46-68). Pretoria: Van Schaik.

Nyathi, T.T. (2007). Academic Performance of Grade 12 learners in Bushbuckridge district. Masters Dissertation. Pretoria: Tshwane University of Technology.

Otis, N.; Grouzet, F.M.E. \& Pelletier, L.G. (2005). Latent motivational change in an academic setting: A 3-year longitudinal study. Journal of Educational Psychology, 97(2), 170-183.

Painter, S.R. (2000). Principals' efficacy beliefs about teacher evaluation. Journal of Educational Administration, 38(4), 368-376.

Pintrich, P.R. \& Schunk, D.H. (2002). Motivation in education, theory, research and application, 2nd edition. New Jersey: Merrill Prentice Hall.

Polit, D.F. \& Beck, C.T. (2008). Nursing research: generating and assessing evidence for nursing practice. 8th edition. Philadelphia: Lippincott Williams and Wilkins.

Ruan, J.M. (2005). Essentials of research methods: a guide to social science research. Oxford: Blackwell.

Schmittou, DM. 2011. The motivating factors of secondary school assistant principals in Southeast Michigan and their impact on job mobility. Doctoral dissertation. Ypsilanti, Michigan: Eastern Michigan University.

Shivers-Blackwell, S. (2006). The influence of perceptions of organisational structure on leadership role requirements: the moderating impact of locus of control and self-monitoring. Journal of Leadership and Organisational Studie, 12 (4), 27-49.

Sikhwivhilu, A.P. (2003). Factors influencing the job satisfaction of female educators. Master's dissertation. Pretoria: University of South Africa.

Suter, W.V. (2006). Introduction to educational research. a critical thinking approach. London: SAGE Publications.

Toffelson, N. (2000). Classroom applications of cognitive theories of motivation. Educational Psychology Review, 12 (1), 63-81.

Tschannen-Moran, M. \& Gareis, C.R. 2004. Principals' sense of efficacy: assessing a promising construct. Journal of Educational Administration, 42(5), 573-585.

Vroom, V. H. (1964). Work and motivation. New York: Wiley. 
Udechukwu, I.I. (2009). Correctional officer turnover: of Maslow's needs hierarchy and Herzberg's motivation theory. Public Personnel Management, 38(2), 69-81.

Wall, C.; Glenn, S.; Mithsinson, S. \& Poole, H. (2004). Using a reflective diary to develop bracketing skills during a phenomenological investigation. Researcher, 11(4), 20-29.

Woods, L.A. \& Olivier, M.A.J. (2004). A self-efficacy approach to holistic student development. South African Journal of Education, 24(4), 289-294. 